\title{
THE BENTHOS OF LAKES
}




\title{
THE BENTHOS OF LAKES
}

\section{RALPH O. BRINKHURST}

\author{
Department of Zoology \\ University of Toronto \\ Toronto, Ontario
}

Now at, Department of the Environment

Fisheries and Marine Service, Biological Station,

St. Andrews, N.B. Canada

\author{
With \\ the collaboration of \\ R. E. BOLTT, M. G. JOHNSON, S. MOZLEY, \\ and A. V. TYLER
}


(C) Ralph O. Brinkhurst 1974

Softcover reprint of the hardcover 1st edition 1974

All rights reserved. No part of this publication may be reproduced or transmitted, in any form or by any means, without permission.

First published 1974 by THE MACMILLAN PRESS LTD

London and Basingstoke

Associated companies in New York Dublin

Melbourne fohannesburg and Madras

SBN 333 I7644 8

ISBN 978-1-349-15558-3 ISBN 978-1-349-15556-9 (eBook)

DOI 10.1007/978-1-349-15556-9 
To all those who have hauled an Ekman by hand from $50 \mathrm{~m}$ in a small boat on a windy day to find a stone caught between the jaws. 


\section{PREFACE}

The purpose of this introduction is to establish the limits of the subject matter that my assistants and I have sought to cover, and to indicate the sort of readers for whom it has been written.

The benthos of a lake is not an harmonious unit, clearly defined by morphometric or functional considerations. To some, the fauna of a lake includes both a littoral and a benthic fauna, as though the bottomdwelling organisms along the shore were distinct from the spatially identified sublittoral and profundal regions. In this volume we treat the benthos as being that assemblage of animals living in or on the sediments and dependent upon the decomposition cycle for most if not all of its basic food supply. The shore fauna is here considered to be comprised of three basic assemblages: that dependent upon wave action on a stony shore, particularly for respiratory needs; that dependent upon the shelter of macrophytic vegetation from which it derives its food supply, the aufwuchs or overgrowth on the weed surface; and the true fauna of the shallow water sediments. Part of the in-fauna may exist in the shallowest parts of the lake in and upon the sediment immediately beneath the weed-associated littoral assemblage, but it is clearly less likely to find suitable accumulations of decomposing organic material on a wave washed stony shore.

Hence the benthos is here considered as the true in-fauna, and especially that inhabiting substrates ranging from sand through mud to silt. This definition underemphasises the problem of the epibenthic forms, particularly the crustaceans, and transitory forms such as Chaoborus, which will have to be dealt with later.

The distinction between a pond and a lake is, of necessity, an artificial one that reflects the difficulty faced by the ecologist in trying to set up categories as reference points for study of what is, essentially, a continuum. The use of the word 'pond' can even be seen to vary regionally, as the ponds of the Atlantic coast of North America would undoubtedly be called lakes by most visitors to the region. Again, we will not endeavour to clarify this, but will draw from information on what would generally be conceded to be lakes, referring to ponds where it is imperative to do so as, for instance, in the section on production studies.

The students of lake benthos have adopted a number of distinct approaches, which will be discussed in detail later on. Two distinct themes can be identified here, however. There are those who have investigated the benthos of a lake or lakes as limnologists, and those who have undertaken to follow their study of a group of organisms (usually a taxonomic unit) into whatever habitat they occupy. Here we are primarily concerned with studies of lakes per se, particularly those in which there is some chemical/physical background data available, and a fairly complete identification of the species involved. Such studies are few, despite the voluminous literature in the field and a general feeling among students that this approach is long outdated. Even scarcer are studies that extend over more than one or two seasons, and it is unfortunately necessary to state that there has never been a study of the benthos of a lake in which, in the senior author's opinion, the sampling methodology and schedule have been properly evaluated, most of the major species identified, and which extended over all seasons for a consecutive number of years.

Despite this total lack of a properly described benthos, we have enough partial accounts, clues, hypotheses and studies of specific components to enable us to lay the plans for such a study. This cannot be done with the resources of any one individual within the academic community, however, hence the most useful contribution that can be made from such a position is to present this review of just what we do and do not know about this aspect of limnology.

It should now be clear that the volume is intended to be, first and foremost, a detailed review for those scientists and senior students working in the field. It may, at the same time, act as a source book for graduate 


\section{Preface}

students, as well as for those responsible for shaping programmes in research institutes. If it does nothing else, it may serve to convince a number of students that ecological research proceeds on many fronts simultaneously. There are architects that conceive structures, and there are those that build brick by brick.

In the direct sense, this is not a book about pollution but the senior author believes that we will never learn to manage our ecosystems until we understand how they work. In the hurried expansion of research activity in lacustrine ecosystems, there has been a gross overdependence on technology and engineering, and far too little attention paid to the living components of the systems that are involved in all the multitude of undesirable pollution symptoms, but there are signs that at least some administrations have recognised this deficiency. What is even worse, living systems have been subject to study as though they were predictable machines-algae are algae regardless of species, eutrophication is equated to ageing as though this were a well-established limnological law. It is to be hoped that some degree of constructive pessimism about the state of the art of benthic research will be communicated to those responsible for many current projects, so that the biologist will be invited to join as an equal in the complex team that will be required to bring about the Ecological Revolution that must supersede the Industrial Revolution.

Finally, the production of a book in such a specialised area may be justified by the need to stimulate benthic research, a field that seems to be languishing compared with more classical limnological and fisheries investigations. Few standard texts concern themselves with the benthos in any detail, and few good contributions to its study appear in current journals. The authors hope that, by reviewing some of the progress in the field to date, a number of younger limnologists may be stimulated enough to remedy some of the deficiencies in our knowledge.

Although the title page indicates a single authorship, this is no more than a matter of convenience. The work of organising my first set of reprints and references was undertaken by Mr. M. Burley who spent a year working with me at Liverpool University. The long delayed project was reactivated in Toronto in 1970, when Dr. S. Mozley translated and abstracted most of the German benthic literature, as well as that dealing with chironomids and lake typology. The section on vertical distribution of benthos, and much of the rest, was researched by Dr. R. E. Boltt; and the production section was prepared and written by Dr. M. G. Johnson; and Dr. A. V. Tyler authored the section on community analysis. I have attempted to draw all these pieces of information together into a single account, and hence bear the responsibility for any errors and omissions arising from the process of rearranging material. I cannot fully express my gratitude to my collaborators and the many assistants who have, in one way or another, contributed so generously to the production of this work. My particular thanks must be expressed to Mr. Frank Miller, who organised a team of students (Cathie Klink, Pauline Barnucz, Diana Nielson and Paul Hagan) at Sheridan College, Oakville, to draw up the illustrations, and especially to Mr. Ted Pulford of The Macmillan Company of Canada Limited, who thoroughly reviewed my manuscript and made many suggestions for the improvement of both content and style. 


\section{Contents}

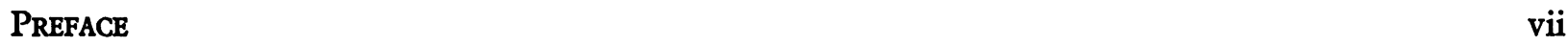

GlossaRY

PART I THE DISTRIBUTION AND ABUNDANCE OF LAKE BENTHOS

Chapter I. Themes in Benthic Research 3

$\begin{array}{ll}\text { Chapter 2. Lake Typology } & 7\end{array}$

Chapter 3. Bathymetric Distribution 30

Chapter 4. Production and Productivity-M. G. Johnson 46

$\begin{array}{ll}\text { Chapter 5. Community analysis-A. V. Tyler } & 65\end{array}$

PART II SOURCES OF VARIABILITY

Chapter 6. Spatial and Temporal Complexity $\quad 87$

Chapter 7. The Sampling Problem $\quad$ I4I

PART III DISCUSSION

Chapter 8. Discussion and Conclusions $\quad$ I59

$\begin{array}{lc}\text { BIBLIOGRAPHY } & \text { I66 }\end{array}$

$\begin{array}{lc}\text { SUBJECT INDEX } & 183\end{array}$

$\begin{array}{ll}\text { GEOGRAPHIC INDEX } & 187\end{array}$

$\begin{array}{lr}\text { TAXONOMIC INDEX } & 189\end{array}$ 


\section{Glossary}

Some terms may cause difficulty for the reader, and so an attempt is made here to explain (rather than define) terms. See also Fundamentals of Limnology, 3rd Ed., Ruttner trs., Frey and Fry, Toronto, 1963.

Allochthonous

Aufwuchs

Autochthonous

Community

(Biocenosis)

Degree-days

Dy

Dystrophic

Emergent

Vegetation

Epibenthic

Epideictic

Eutrophic

Glacial Relict

Gyttja

Humus (humic)

Indicator

Organisms

Internal

Seiche

Lacustrine

Littoral

Macrobenthos

Meromictic

Monomictic

Mesohumic

Mesosaprobic
Organic material formed primarily by photosynthesis, outside the system under consideration (cf. Autochthonous).

Microscopic plant and animal forms which encrust submerged surfaces, both living and non-living; a rich food source for grazers.

Organic matter which originates within the system under consideration, primarily by photosynthetic activity (cf. Allochthonous).

Groups of organisms found in a habitat, more closely related to each other ecologically than they are to other such groups.

Where a biological process is related to temperature, such that completion would be achieved in 20 days at $10^{\circ}$ or Io days at $20^{\circ}$, either being equal to 200 degree-days.

A bottom deposit of precipitated humic colloids (cf. Gyttja).

See Trophic Gradient.

Plants with leaves and other parts above water level but with submerged roots (cf. submerged and floating vegetation: plankton).

Superficially benthic organisms of the mud/water interface.

Adapted for display.

See Trophic Gradient.

Survivors of the Pleistocene biota restricted to particular localities by reason of glacial history and/or temperature tolerance.

Finely divided organic detritus on lake bottoms; sediment typical of aerobic lake bottoms (seemingly most organic muds as opposed to peaty muds, or Dy).

Partly decomposed organic material, soil tending to peat.

Organisms supposedly with narrow environmental tolerance used as indicators of environmental stress. Sensitive species may indicate stress by their absence, tolerant species confuse people by living in small numbers in 'clean' or natural localities. Indicator communities are preferred (see Saprobien System).

A standing wave in a lake; the result of piling up of warm surface water at one end of the lake and consequent displacement of cool bottom water at the other and the subsequent oscillations of the discontinuity layer in restoring itself to the horizontal in thermally stratified lakes.

Pertaining to lakes.

(Also sublittoral). Relative to depth distribution. In marine biology usually that area exposed by rise and fall of tide. In limnology usually the shallowest part of the lake variously defined, equivalent to sublittoral of marine biology (see chapter 3).

(Microbenthos, meiobenthos). Organisms visible to the naked eye. Microbenthos may be restricted to bacteria et al. but may include all forms not visible to the naked eye (i.e. nematodes).

A lake in which the water mass does not mix or circulate (see Mixis).

A lake in which the water is mixed or circulates once a year (see Mixis).

Moderately humic (or peaty) as opposed to poly, oligo humic, etc., see also Dystrophicchapter 2 (table 2.4).

See Saprobien System. 


\section{Glossary}

Mesotrophic

Mixis

Oligosaprobic

Oligotrophic

Poisson

Distribution

Polysaprobic

Profundal

R.Q.

Saprobien System

Secondary
Production

Stenothermy

Trophic

Gradient

Turnover Ratio

Voltine
See Trophic Gradient.

The annual frequency with which a lake 'turns over' or stratification breaks down (amictic, dimictic, meromictic, monomictic, polymictic, etc. q.v.).

See Saprobien System.

See Trophic Gradient.

In statistics, a series which gives the frequency with which groups of zero, one, two etc., organisms will be encountered together if distribution is random.

See Saprobien System.

Of the deeper part of a lake; not definable (see chapter 3 ) cf. littoral.

Respiratory quotient; the ratio of $\mathrm{CO}_{2}$ evolved to $\mathrm{O}_{2}$ used in respiration.

A system akin to that of the Trophic System or Trophic Gradient, by which organisms are related to degree of pollution (usually organic) or lack of oxygen in an ecosystem. An attempt to schematise the indicator species concept, now tremendously elaborated (Sladecek. Arch. F. Hydrobiol. 7: 1973). A pseudoquantitative construct as fallible as the Trophic System with the same rudiments of common sense. Grades of Oligo-MesoPolysaprobic minutely subdivided in some schemata.

Energy or materials stored by photosynthesis referred to as primary production; the quantities stored by consumers are hence secondary production. Standing stock (often miscalled standing crop) often misused for secondary production, i.e. the static measure may not reflect the dynamic concept.

Having a narrow temperature tolerance (cold s., warm s.).

The lake series oligotrophic (superficially meaning unproductive)-mesotrophiceutrophic (or highly productive) properly overlaid with a second dimension in relation to humic content or degree of Dystrophy (usually ignored in recent literature or thought of as fourth lake type), often assumed to represent evolutionary phases in lake history as in the transition to dry land. The terminal phases of this process lead to morphometric eutrophy-enhanced plant production, warm turbid water, rich in nutrients, coarse fish instead of game fish, deoxygenated mud, etc. Lake basins may, in fact, run low in nutrients and lakes become oligotrophic (less productive) with time. Never properly defined. See chapter 2.

Ratio of throughput to content; in the production sense, the relationship between standing stock and production per unit time; production per unit biomass per unit time. Number of generations in a year (Univ., Biv.). 